\title{
PENINGKATAN PENGETAHUAN ORANG TUA TENTANG BAHAYA MEROKOK DALAM RUMAH DAN PENCEGAHAN ISPA PADA BALITA
}

\author{
Amila ${ }^{1}$, Jek Amidos Pardedei ${ }^{2}$, Galvani Volta Simanjuntak ${ }^{3}$, Yasinta L.A Nadeak ${ }^{4}$ \\ ${ }^{1,2,3,4}$ Program Studi Keperawatan Universitas Sari Mutiara Indonesia, Medan, Indonesia \\ Email : ${ }^{1}$ mila_difa@yahoo.co.id, ${ }^{2}$ jekpardedemi@ rocketmail.com, \\ 3 galvanisimanjuntak@yahoo.co.id
}

\begin{abstract}
ABSTRAK
Infeksi Saluran Pernapasan Akut (ISPA) adalah gangguan saluran pernapasan yang sering terjadi dan merupakan penyakit yang masih dianggap remeh oleh masyarakat Indonesia. Pajanan asap rokok dalam rumah merupakan faktor utama pencemaran udara dalam ruangan yang menyebabkan gangguan pada saluran pernapasan, khususnya pada kelompok balita. Kecenderungan orang tua untuk merokok di dalam rumah membuat anak balita menjadi perokok pasif yang sering terpapar asap rokok. Tujuan kegiatan pengabdian kepada masyarakat adalah meningkatkan pengetahuan orangtua yang mempunyai kebiasaan merokok di dalam rumah dengan ISPA pada anak balita, mendemonstrasikan tanda dan gejala ISPA, dan mendukung program pemerintah GERMAS (Gerakan Masyarakat Hidup Sehat) dimana salah satu programnya adalah tidak merokok di wilayah kerja Puskesmas Saitnihuta Provinsi Sumatera Utara. Solusi permasalahan kebiasaan orang tua merokok di dalam ruangan adalah pemberian edukasi dan sosialisasi tentang bahaya merokok di dalam ruangan melalui media leaflet dan brosur. Setelah kegiatan pengabdian kepada masyarakat dilakukan, pengetahuan orang tua meningkat dan orang tua memahami bahaya merokok di dalam rumah sehingga terjadi perubahan pola hidup sehat untuk mencegah kejadian ISPA pada balita.
\end{abstract}

Kata Kunci: Merokok, ISPA, Balita

\section{ABSTRACT}

Acute Respiratory Infection (ARI) is a respiratory tract disorder that often occurs and is a disease that is still underestimated by the people of Indonesia. Exposure to cigarette smoke in the house is the main factor in indoor air pollution that causes respiratory tract disorders, especially in the toddler group. The habit of parents smoking in the house makes toddlers as passive smokers who are always exposed to cigarette smoke. The purpose of community service activities is to increase the knowledge of parents who have a smoking habit in the house with the incidence of ARI in toddlers, demonstrate the signs and symptoms of ARI, and support the government program GERMAS (Healthy Living Community Movement) where one of the programs is not smoking in the working area of the Saitnihuta Public Health Center in North Sumatera Province. The solution to the problem of parental smoking habits in the room is the provision of education and socialization about the dangers of smoking indoors through leaflets and brochures. After community service activities are carried out, parents' knowledge increases and parents understand the dangers of smoking in the house so that there is a change in healthy lifestyle behavior to prevent the incidence of ARI in toddlers.

Keywords : Smoking, Acute Respiratory Infection, Toddler 


\section{PENDAHULUAN}

Infeksi Saluran Pernapasan Akut (ISPA) adalah gangguan saluran pernapasan yang sering terjadi dan merupakan penyakit yang masih dianggap remeh oleh masyarakat Indonesia (Zhafirah \& Susanna, 2020). ISPA jika tidak ditangani dengan baik dapat menyebabkan komplikasi serius seperti infeksi pada paru, infeksi pada selaput otak, penurunan kesadaran, gagal napas, bahkan menimbulkan kematian khususnya pada anak balita yang belum memiliki imunitas yang kuat (Widoyono, 2011, Aryani \& Syapitri, 2018). Infeksi saluran pernapasan akut merupakan infeksi akut dengan melibatkan organ pernapasan bagian atas dan bawah yang penyebabnya adalah virus, jamur dan bakteri. Diperkirakan tiap anak terkena ISPA 3-6 kali setiap tahunnya, (Baladiah, 2019).

Lebih dari $50 \%$ kematian pada balita di berbagai negara berkembang disebabkan karena infeksi saluran pernafasan akut (Kemenkes RI, 2017). WHO melaporkan pada tahun 2015 angka kematian anak balita hampir 6 juta, 16\% diantaranya disebabkan oleh pneumonia (satu dari beberapa manifestasi ISPA) (IDAI, 2016). Berdasarkan hasil Riskesdas (2018) prevalensi ISPA di Indonesia sebesar 9,3\% dengan prevalensi ISPA tertinggi terjadi pada kelompok usia satu sampai empat tahun sebesar 13,7\% dan untuk Provinsi Sumatera Utara Prevalensi ISPA sebesar 6,8\% (Kementerian Kesehatan RI, 2018).

Tingginya angka kejadian infeksi saluran pernapasan akut pada anak balita dipengaruhi atau ditimbulkan oleh beberapa faktor yaitu adanya mikrobakteri, system imun balita dan kondisi lingkungan rumah. Kondisi lingkungan rumah tangga yang dapat mempengaruhi kualitas udara dalam ruangan antara lain asap tembakau atau paparan asap rokok di dalam rumah (Zahra \& Assetya, 2018). Paparan asap rokok di rumah merupakan faktor utama polusi udara dalam ruangan yang menyebabkan penyakit pernapasan, terutama di kalangan anak balita (Zahra \& Assetya, 2018).

Kebiasaan merokok orang tua di rumah membuat anak kecil menjadi perokok pasif, dan mereka selalu terpapar asap rokok. WHO menyatakan bahwa efek buruk asap rokok lebih besar bagi perokok pasif dibandingkan perokok aktif. Ketika seorang perokok membakar sebatang rokok dan menghirupnya, asap yang dihisap si perokok disebut asap utama, dan asap yang keluar dari ujung (bagian pembakaran) rokok disebut asap sampingan. Fakta membuktikan bahwa asap sampingan ini lebih banyak mengandung hasil pembakaran tembakau dibandingkan asap utama. Asap ini mengandung karbon monoksida 5 kali lipat, tar dan nikotin 3 kali lipat, amonia 46 kali lipat, nikel 3 kali lipat, dan nitrosamin sebagai konsentrasi karsinogenik (Umami, 2010).

Penelitian Fillacano (2013) mendapatkan bahwa orang tua yang mempunyai kebiasaan merokok di rumah meningkatkan peluang kejadian ISPA pada balita sebesar 7,83 kali bila dibandingkan dengan orang tua tidak merokok di dalam rumah. Asap rokok yang dihirup dapat menyebabkan gangguan fungsi silia, peningkatan volume lendir, perubahan antigen cairan tubuh, dan perubahan kuantitatif dan kualitatif pada komponen seluler. Beberapa perubahan mekanisme pertahanan tersebut dapat kembali normal jika telah terbebas dari pajanan asap rokok. Oleh karena itu, selama pasien ISPA masih terpapar asap rokok, pertahanan tubuh terhadap infeksi tetap terganggu (Baladiah, 2019).

Berdasarkan hasil survei yang dilakukan di Puskesmas Saitnihuta, jumlah kejadian ISPA pada balita meningkat setiap tahunnya. Tahun 2018 terdapat 2128 kasus ISPA pada balita, meningkat menjadi 2362 kasus tahun 2019 dan tahun 2020 meningkat lagi menjadi 2514 kasus. Berdasarkan hasil wawancara yang dilakukan di Puskesmas Saitnihuta terhadap 10 keluarga yang mempunyai anak berumur 1-5 tahun menderita ISPA, 
diperoleh informasi bahwa 7 orang tua perokok dan 3 tidak merokok. Selain itu, petugas puskesmas yang memegang program ISPA menyampaikan bahwa ISPA merupakan penyebab utama balita dibawa ke Puskesmas. Untuk itu perlu edukasi kepada masyarakat/orangtua yang mempuyai kebiasaana merokok dalam ruangan untuk pengendalian kejadian ISPA pada Balita dan modifikasi gaya hidup, sehingga pasien/Balita dengan gejala ISPA berkurang atau dapat ditekan serendah mungkin dan kualitas hidup dapat ditingkatkan.

Tujuan kegiatan pengabdian kepada masyarakat adalah meningkatkan pengetahuan masyarakat (orangtua) yang mempumyai kebiasaan merokok di dalam rumah tentang kejadian ISPA pada balita, mendemonstrasikan tanda dan gejala ISPA, dan mendukung program pemerintah GERMAS (Gerakan Masyarakat Hidup Sehat) dimana salah satu programnya adalah tidak merokok. Manfaat kegiatan pengabdian masyarakat adalah pencegahan kejadian ISPA pada anak balita, modifikasi gaya hidup dengan mengubah kebiasaan merokok di dalam ruangan, menurunkan angka kematian akibat penyakit ISPA baik secara nasional maupun global dan memberikan informasi kepada orang tua dan masyarakat dalam rangka meningkatkan perilaku pencegahan kebiasaan merokok untuk mengurangi kejadian ISPA pada balita.

\section{Metode}

Metode kegiatan diberikan dalam bentuk edukasi. Pendidikan kesehatan merupakan kunci utama untuk merubah faktor risiko dan gaya hidup masyarakat. Sasaran kegiatan pengabdian kepada masyarakat adalah ibu-ibu di wilayah kerja UPT Puskesmas Saitnihuta yang beralamat di Desa Saitnihuta Kecamatan Dolok Sanggul Kabupaten Humbang Hasundutan Provinsi Sumatera Utara berjumlah 30 orang. Kegiatan dilaksanakan pada hari Selasa - Rabu pada tanggal 4-5 Juli 2021. Waktu pelaksanaan dimulai jam 09.00- s.d 12.00 WIB.

Metode yang digunakan untuk pemecahan masalah dalam kegiatan ini adalah (1) melakukan pretest dan postest sebelum pemberian materi untuk mengetahui perubahan sikap dan pengetahuan mengenai dampak kebiasaan merokok dalam rumah dengan kejadian ISPA, (2) pemberian materi kepada orang mengenai dampak kebiasaan merokok dalam rumah dengan kejadian ISPA menggunakan ceramah dan demontrasi (3) pemberian poster atau leaflet tentang ISPA pada balita dan (4) Focus Group Discussion (FGD) dengan orang tua untuk mengevaluasi keberhasilan edukasi. Materi penyuluhan, yaitu ISPA, (penyebab, tanda dan gejala klinis), bahaya merokok dengan kejadian ISPA pada balita .

Media yang digunakan adalah (1) laptop yang digunakan untuk presentasi materi yang bentuk power point, (2) leaflet dan poster tentang ISPA dan (3) FGD (Focus Group Discussion).

\section{Hasil dan Pembahasan}

Kehadiran peserta saat penyuluhan berjumlah 30 orang yang diikuti oleh orang tua, pihak Puskesmas dan tim Universitas Sari Mutiara Indonesia. Pelaksanaan kegiatan 
sesuai dengan rencana yang telah disepakati. Antusias peserta dalam kegiatan ini sangat tinggi dibuktikan dengan banyaknya pertanyaan dari peserta

Sebelum diberikan penyuluhan, para siswi diberikan pertanyaan oleh tim untuk menilai sejauh mana tingkat pengetahuan para peserta mengenai merokok dan ISPA pada balita dan demonstrasi tanda dan gejala penyakit ISPA. Selanjutnya dilakukan pemaparan tentang pengertian penyakit ISPA, factor risiko ISPA, angka kejadian ISPA pada balita, kebiasaan orang tua merokok dalam rumah, , tanda dan gejala ISPA, pencegahan ISPA, pengobatan dan perawatan ISPA pada balita. Penyuluhan dilakukan secara lisan melalui ceramah dan demonstrasi, pembagian leaflet tentang merokok dan ISPA pada balita. Pengetahuan yang didapat dari penyuluhan diharapkan dapat menjadi dasar bagi orang tua untuk tidak merokok dalam rumah, sehingga dapat mencegah ISPA pada balita.
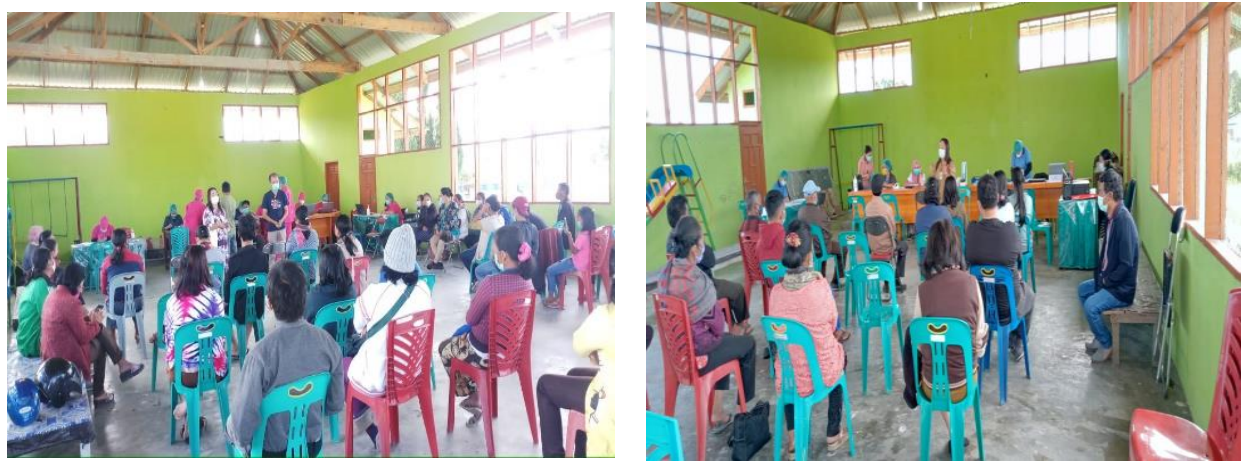

\section{Gambar 1.1 Edukasi orang tua}

Infeksi saluran pernapasan akut (ISPA) merupakan salah satu penyakit yang menyerag saluran pernapasan baik atas maupun bawah. Penyakit ini menular dengan variasi gejala mulai dari gejala ringan sampai berat dan dapat menyebabkan kematian, tergantung dari penyebabnya, faktor lingkungan serta penjamu. ISPA dapat muncul karena adanya paparan dari virus maupun bakteri misalnya bakteri dari genus streptococcus, staphylococcus haemophylus dan pneumococcu, dan jenis virus influenza, rhinovirus dan parainfluena,. Selain dari bakteri dan virus serta jamur, ISPA juga dapat disebabkan karena paparan asap rokok atau asap kendaraan bermotor dan cairan amonium pada saat lahir (Utami, 2013). Gejala ISPA biasanya timbul dengan cepat, yaitu dalam waktu beberapa jam sampai beberapa hari. Gejalanya meliputi demam, batuk dan sering nyeri tenggorokan,

Di Indonesia, ISPA masih merupakan salah satu masalah kesehatan masyarakat yang utama terutama pada bayi (0-11bulan) dan balita (1-4 tahun). Di Indonesia, kejadian ISPA pada balita diperkirakan sebesar 10-20\% (Chandrawati \& Alhabsyi, 2017).

Merokok masih merupakan masalah kesehatan masyarakat yang sangat besar. Jutaan anak menderita efek merugikan dari perokok pasif. Semakin banyak negara baru-baru ini mengeluarkan undang-undang untuk mengatur merokok di tempat umum. sebaliknya, rumah tetap menjadi situs di mana balita dan anak-anak sering terpapar bahaya asap tembakau. Di Indonesia, Kebiasaan orang tua merokok di dalam rumah menjadi masalah yang cukup mengkhawatirkan. Merokok di dalam rumah menjadi salah satu faktor penyebab masalah kesehatan di dalam keluarga seperti gangguan pernafasan dan juga 
meningkatkan serangan ISPA terutama pada anak balita. Anak-anak yang memilik orang tua perokok lebih rentan terkena penyakit pernafasan Wardani, Winarsih \& Sukini, 2015). Hasil penelitian Hilmawan dkk., (2020) bahwa ada hubungan kebiasaan merokok dengan kejadian ISPA pada balita di Kelurahan Sukajaya Kecamatan Purbaratu Kota Tasikmalaya

Keterpaparan asap rokok pada balita sangat tinggi, hal ini disebabkan karena anggota keluarga yang merokok biasanya merokok dalam rumah pada saat bersantai bersama anggota keluarga yang lainnya, misalnya pada saat menonton atau setelah selesai makan. Paparan yang terus menerus akan menimbulkan gangguan pernafasan terutama memperberat timbulnya infeksi saluran pernafasan akut dan gangguan. Zat berbahaya dalam asap rokok memicu pembentukan lender sehingga bakteri dan debu yang terhirup akan menunpuk dan sulit dikeluarkan, menimbulkan bronchitis kronis, lumpuhnya serat elastis di jaringan paru-paru yang berakibat pada pecahnya alveoli (Aprilla, dkk., 2019).

Selama pelaksanaan animo peserta sangat baik dalam menerima edukasi bahaya merokok di dalam rumah dan pencegahan ISPA pada balita. Pelaksanaan kegiatan ini menggunakan metode ceramah, untuk memberikan informasi yang berkaitan dengan pendidikan kesehatan kepada masyarakat.

\section{Kesimpulan}

Pengetahuan orang tua yang mempuyai kebiasaan merokok dalam ruangan sebagai faktor risiko kejadian ISPA pada balita meningkat dan modifikasi lingkungan sebagai upaya pencegahan ISPA pada balita dilaksanakan dengan baik oleh orang tua. Hasil kegiatan pengabdian kepada masyarakat diharapkan kepada orang tua untuk meningkatkan kesadarannya meninggalkan kebiasaan merokok dan menciptakan lingkungan yang sehat dan bersih dari asap rokok untuk mengurangi kejadian ISPA pada balita dan mendukung program pemerintah GERMAS (Gerakan Masyarakat Hidup Sehat) dimana salah satu poinnnya adalah tidak merokok .

\section{Ucapan Terima Kasih}

Kami dari tim program kemitraan masyarakat (PKM) mengucapkan terima kasih kepada Bapak kepala puskesmas, tim puskesmas yang sudah memberikan waktu dan kesempatan kepada tim dosen USM Indonesia untuk melakukan salah satu Tridarma di Perguruan Tinggi.

\section{Referensi}

Aprilla, N., Yahya, E., \& Ririn. (2019). Hubungan antara Perilaku Merokok pada Orang tua dengan Kejadian ISPA pada Balita di Desa Pulau Jambu Wilayah Kerja Puskesmas Kuok Tahun 2019. Jurnal Ners, 3(1), 112-118.

Aryani, N., \& Syapitro, H. (2018). Hubungan Kebiasaan Merokok Anggota Keluarga Di Dalam Rumah Dengan ISPA Pada Balita Di Puskesmas Helvetia Tahun 2016. 1Jurnal Kesehatan Masyarakat Dan Lingkungan Hidup, 3(1), 1-9.

Baladiah, B. J., Srw, D. W., Putri, M. N., Nisa, K., Kedokteran, F., Lampung, U., Ilmu, B., Komunitas, K., Kedokteran, F., Lampung, U., Fisiologi, B., Kedokteran, F., \& Lampung, U. (2019). Kebiasaan Merokok dan Status Gizi Kurang sebagai Faktor Risiko Kejadian ISPA di Wilayah Kerja Kemiling Bandar Lampung Smoking Health 
and Undernutrition is as A Risk Factors of Acute Respiratory Infection in Children under Five Years in Kemilin. 8, 168-174.

Chandrawati, P. F. (2017). HUBUNGAN BERAT BADAN LAHIR RENDAH TERHADAP FREKUENSI KEJADIAN ISPA masyarakat yang utama terutama pada bayi ( 0-11 Beberapa faktor yang mempengaruhi tidak langsung . Faktor risiko yang menyebabkan berat badan lahir rendah ( BBLR ), status gizi buruk, Dat. Bagian Ilmu Kesehatan Anak, Fakultas Kedokteran Universitas Muhammadiyah Malang, Vol. 10 No(Fakultas Kedokteran Universitas Muhammadiyah Malang), 3136. http://ejournal.umm.ac.id/index.php/sainmed/article/view/4145/4518

Fillacano, R. (2013). Hubungan lingkungan dalam rumah terhadap ISPA pada BALITA di Kelurahan Ciputat Kota Tangerang Selatan Tahun 2013.

Hilmawan, R. G., Sulastri, M., \& Nurdianti, R. (2020). Hubungan kebiasaan merokok dengan kejadian ISPA pada balita di Kelurahan Sukajaya Kecamatan Purbaratu Kota Tasikmalaya. Jurnal Keperawatan \& Kebidanan, 4(1), 9-16.

Kemenkes RI. (2018). Laporan Provinsi Sumatera Utara Riskesdas 2018. In Badan Penelitian dan Pengembangan Kesehatan. http://www.litbang.kemkes.go.id:8080/handle/123456789/84372

Umami, R. M. (2012). Perancangan Dan Pembuatan Alat Pengendali Asap Rokok Berbasis Mikrokontroler At89S8252. Jurnal Neutrino, 2(2), 155-163. https://doi.org/10.18860/neu.v0i0.1636

Wahyuni, N. M. H., Mirayanti, N. K. A., \& Eka Sari, N. A. M. (2020). Hubungan Perilaku Merokok Orang Tua Dengan Kejadian Infeksi Saluran Pernapasan Akut Pada Balita Di Uptd Puskesmas Tabanan Iii. Bali Medika Jurnal, 7(1), 11-23. https://doi.org/10.36376/bmj.v7i1.94

Wardani, N. K., Winarsih, S., \& Sukini, T. (2015). Hubungan Antara Paparan Asap Rokok Dengan Kejadian Infeksi Saluran Pernapasan Akut (ISPA) Pada Balita Di Desa Pucung Rejo Kabupaten Magelang, Tahun 2014. Jurnal Kebidanan, 4(8), 1825.

WHO. (2020). Manual praktis untuk mengatur dan mengelola pusat pengobatan ISPA dan fasilitas skrining ISPA di fasilitas pelayanan kesehatan. World Health Organization, 100. (WHO/2019-nCoV/SARI_treatment_center / 2020.1)

Widia, L. (2017). Hubungan Antara Status Gizi dengan Kejadian ISPA pada Balita. Jurnal Darul Azhar, 3(1), 28-35.

Widoyono, (2011). Penyakit Tropis Epidemiologi, Penularan, Pencegahan, dan Pemberantasannya Jakarta : Erlangga.

Zhafirah, N., \& Susanna, D. (2020). Perilaku Hidup Bersih dan Sehat (PHBS) dengan Kejadian Gangguan Pernapasan pada Balita di Kawasan Pesisir Desa Sedari, Kecamatan Cibuaya, Karawang, Jawa Barat Tahun 2018. Jurnal nasional Kesehatan Lingkungan Global, 1(1). 